\title{
African elephants: population trends and their causes
}

I. Douglas-Hamilton

In 1985 many African elephant populations, which had been monitored for a decade or more, were either in rapid decline or down to a fraction of their former size. The author examines regional trends and information on key populations with reference to the critical factors affecting the survival of the African elephant, most significantly poaching and the illegal trade in ivory.

Before the mid 1970s, surprisingly little reliable information was available on the numbers and distribution of the African elephant Loxodonta africana sp. By 1979 data were still scanty, but a continental survey estimated approximately one million elephants in a large number of fragmented populations. The general downward trend was already evident (Douglas-Hamilton, 1979a). In the past few years, elephants appear to have been virtually eliminated in certain areas within Sudan, Chad, the Central African Republic and Zaire, and have been greatly reduced in East, South and West Africa. Exceptions to this general rule are found in Zimbabwe, Malawi, Botswana and South Africa.

A variety of factors has been implicated in the increased mortality of elephants, including poaching for meat or ivory, habitat destruction, drought and disease. The development and implementation of effective conservation measures clearly depend upon identification of the most critical factors. This article argues that poaching for ivory is the most immediate threat to the elephants' future, and habitat loss is the longterm threat. Historically, elephant populations have been exterminated by ivory hunters alone, in North Africa in the early Middle Ages (Carrington, 1958), in most of South Africa in the eighteenth and nineteenth centuries (Bryden, 1903), and in most of West Africa in the late nineteenth and early twentieth century (DouglasHamilton, 1979b).

African elephants: population trends
In the 1970s rising ivory prices in combination with the proliferation of automatic rifles in much of Africa have led once again to enormous destruction of elephant populations. If not halted or controlled, the continuation of poaching at current levels may rapidly deplete even the most 'secure' populations. Anti-poaching measures accompanied by elimination of or rigorous control over the ivory trade should be the top priorities for conservationists.

\section{Elephant population trends}

Trends in some key elephant populations are summarized below. The data have been compiled from a variety of sources, including over 150 aerial surveys ( 30 made by the author), the scientific literature and, since 1976, 124 responses to a series of IUCN elephant questionnaires*. Methods used ranged from statistical sampling to informed estimation by local wildlife officials. The charts in Figure 1 show my interpretation of probable trends for 19 areas within the period 1960-1985. The data are adjusted to an index value of 100 in 1970 , or in the first following year in which they became available. There are still great uncertainties about the total number of elephants in Africa; approximately 42 per cent of their range contains forest where it is

*Many of the surveys and all the questionnaires were financed by WWF and NYZS under the auspices of the IUCN Species Survival Commission. 


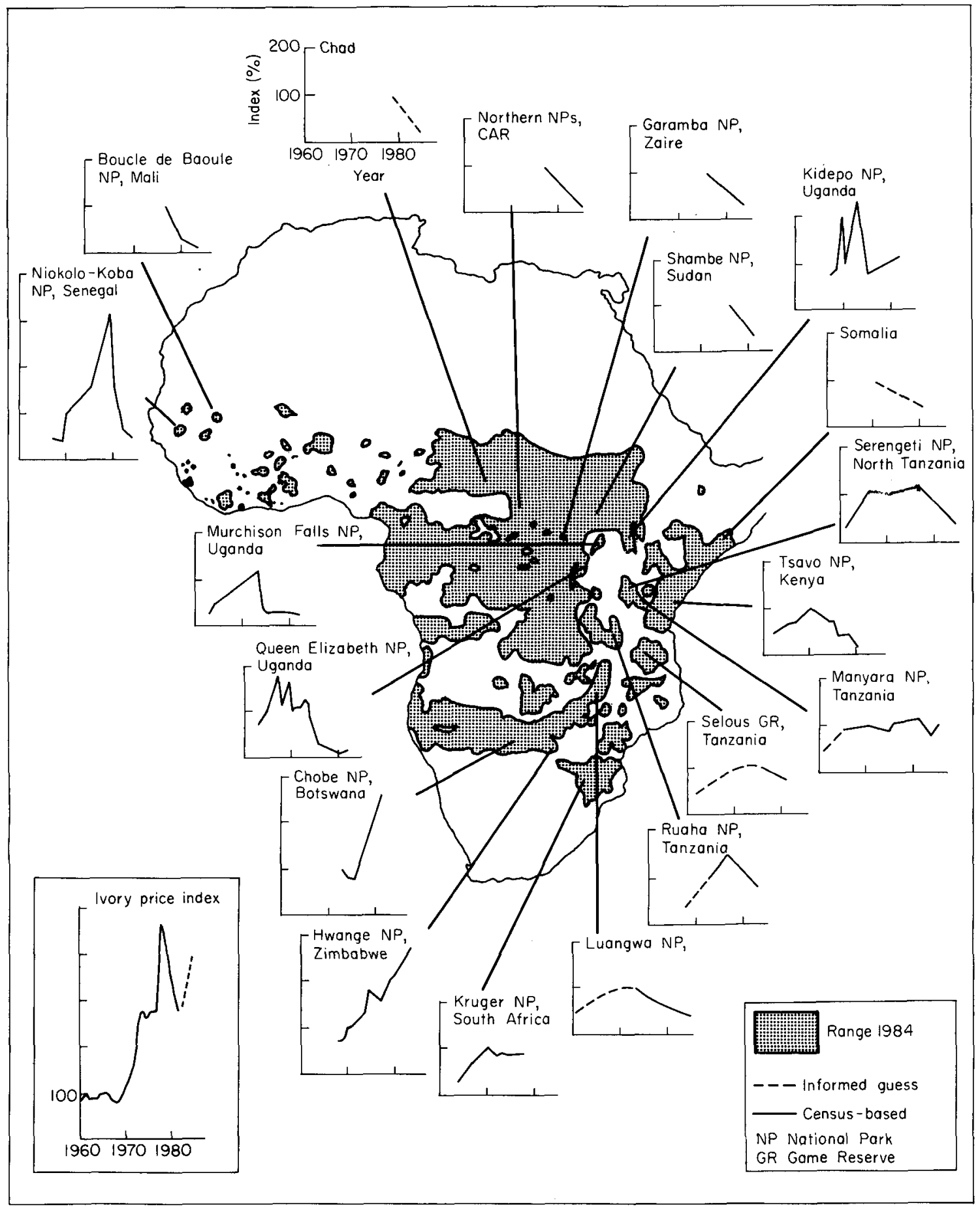

Figure 1. Distribution map and trend indices for selected African elephant populations, 1960-85, including index of 
difficult or impossible to count from the air. The trends, however, are much clearer, even in the forest.

Two general patterns are evident. Firstly, most populations, whether in 'protected' areas or not, are now in decline (exceptions are found in Zimbabwe, South Africa, Botswana and Malawi). Secondly, in most 'protected' areas declines have been preceded by increases, so that the population density plotted over time shows a humpback curve. The initial increases are best explained by the widely accepted hypothesis that parks and reserves tend to attract 'refugee' elephants escaping external harassment or habitat encroachment. Improved census technique also contributed to apparent increases in some cases. The pattern of subsequent declines in protected areas is explained in most cases by intensified ivory poaching after external sources have been depleted.

Thus, rapid population increases within protected areas, which might be interpreted as healthy, growing elephant populations, may in reality represent an early warning of poaching or other disturbance outside the park or reserve boundaries. Such poaching may ultimately threaten the protected areas themselves.

The following examples, although fragmentary and not comprehensive, serve to illustrate the trends across the continent.

\section{West Africa (elephant range 364,000 sq $\mathrm{km}$; 5 per cent of total range)}

Most elephants were eradicated from West Africa in the early part of this century. Ivory exports increased and then collapsed despite continuously rising prices before 1914. It is possible that the ivory trade over-exploited the resource and caused a crash (Douglas-Hamilton, 1979b). Scientific data are lacking from that time, but contemporary accounts of administrators and hunters support this hypothesis. Today, elephants survive in scattered, relict populations, threatened by both ivory poaching and loss of habitat associated with high human population densities.
In the savannahs and Sahel of the north, the westernmost population is in the Niokola-Koba National Park, in Senegal. Aerial counts show an increase from an estimated 69 elephants in 1967 to a maximum of 450 in 1979 (Dupuy, questionnaire replies). Then the population rapidly collapsed to about 80 in 1984, attributed to ivory poaching by well-armed poachers (Verschuren, 1981).

In the northern semi-desert of Mali, the Gourma region supports a few hundred elephants now said to be declining due to drought (La Marche, questionnaire replies; Olivier, 1983). In the Guinean forest, aerial surveys in Boucle de Baoule, Mali, failed to locate elephants in 1981 (De Bie and Kessler, 1983). It is possible that between five and seven elephants survive out of the population estimated at 70 in 1977, and 20 in 1980. The population south-east of Bamako has declined, from 60 in 1974 to 35 in 1980 and fewer than 20 in 1985. Professional ivory poachers with heavy guns were said to be the cause. Elsewhere in Mali four populations are said to have disappeared altogether, and other populations are believed to be in severe decline (La Marche, questionnaire replies).

The largest Guinean savannah woodland elephant range includes Parc W, shared between Burkina-Faso, Niger and Benin, with the neighbouring Pendjari and Arli National Parks (Bousquet and Szaniawski, 1981). Immigration of elephants is believed to have swollen numbers in the last 20 years, but ivory poaching has been perceived to be a problem since 1982 (Newby, questionnaire reply).

The elephant subspecies Loxodonta a. cyclotis, found in the forests of Ivory Coast, Liberia, Sierra Leone and Ghana, is reported to be in decline and endangered (Roth et al., 1984; Teleki, 1980; Verschuren, 1982; questionnaire replies). In Ivory Coast elephants ranges are fragmented into 35-40 isolated populations and have diminished by more than 80 per cent since the turn of the century. Currently, poaching for ivory is reported as the main cause of the estimated 10 per cent annual rate of decrease (Roth et al., 1984). Togo appears to be an exception to the general rule, with two small protected populations of elephants 


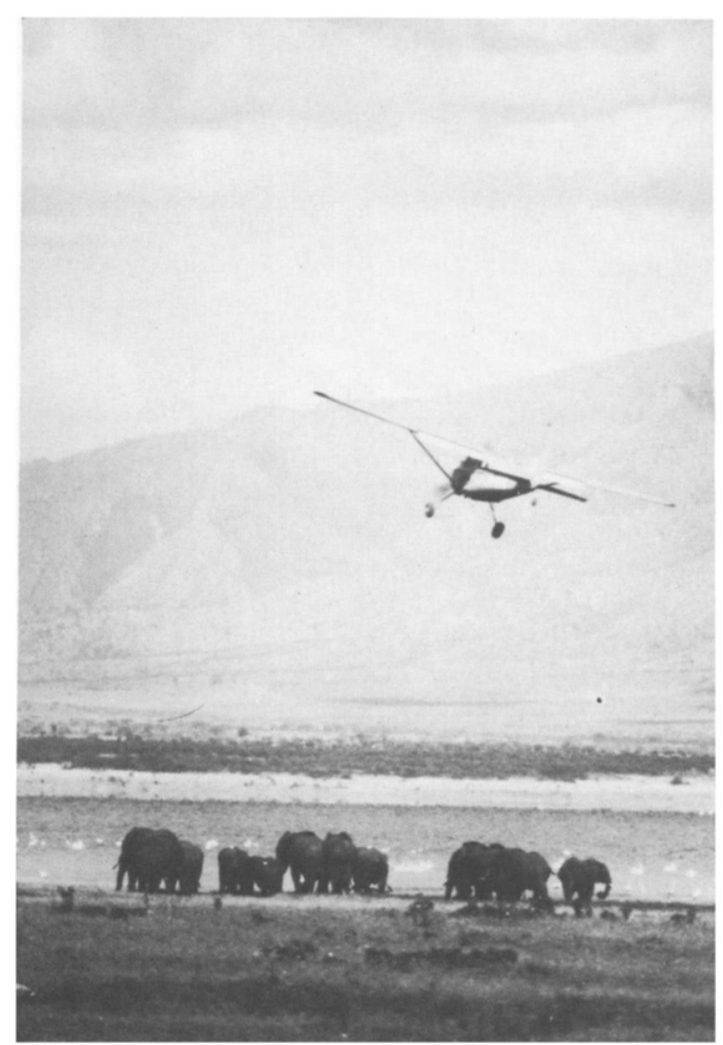

Author's aeroplane being used to count elephants in Lake Manyara National Park during the WWF/NYZS African elephant survey and conservation programme (I. and O. Douglas-Hamilton).

said to suffer little from poaching (Duncan, questionnaire reply).

Most of Nigeria's elephants are found in the Yankari Game Reserve and Kainji National Park, where the populations have shown a natural increase. Elsewhere, elephants live in small, scattered, relict populations, which, although mainly confined to forest or game reserves, are believed to be declining. Until recently the main causes have been poaching for meat and expansion of people into the elephants' range. One possible exception is the 100 or so elephants living near Lake Chad in the far north-east of the country. Although these elephants are not officially protected within a reserve, they are said to be protected by a continuing local tradition that forbids the killing of elephants (Hall, questionnaire replies).
Central Africa (elephant range $3,372,000 \mathrm{sq} \mathrm{km} ; 48$ per cent of total range)

Central Africa probably still harbours the largest proportion of Africa's elephants by virtue of the immense range and the high proportion of forest, which gives the elephants greater shelter from human predation than the open savannah. Each country in the region still possesses major elephant ranges.

Cameroon. Elephants are said to have increased in both the Waza and Kalamaloue National Parks through immigration from Chad, where a civil war has been raging, but some of this conflict has spilled over the border, and poaching with automatic rifles has recently been reported in the north. There is a risk that they may begin to decrease if they have not already done so. In southern forested areas elephants are reported to have been greatly depleted by ivory poaching (Douglas-Hamilton, 1979b; questionnaire replies).

Central African Republic. An uncontrolled ivory trade, which encouraged villagers to poach by furnishing them with guns, has led to the decimation of elephants in the south-east, renowned for its large tuskers in the late 1970s (DouglasHamilton, 1980; Mulder and Caro, 1980). In the north horsemen from Sudan and Chad have slaughtered elephants both with long spears and with automatic rifles. Aerial surveys of the Bamingu-Bangoran and Manovo-Gounda National Parks in 1985 revealed a decline in elephants of the order of 80 per cent since 1981 (Douglas-Hamilton et al., 1985). The supply of large tusks has now virtually dried up, and big bull elephants are rare. The toll has fallen on everyounger age groups (Froment, 1985; Wells and Douglas-Hamilton, 1986). The most recent estimate is of 10,000-15,000 elephants in 1985, compared with the first estimate of some $80,000-$ 100,000 in 1976 (Douglas-Hamilton et al., 1985; Froment, 1985). A total ban on all private ivory trading was seen by the government as the only possible solution, and this was enforced in 1985. A zero export quota has been declared to the Convention on International Trade in Endangered Species of Wild Fauna and Flora (CITES) Secretariat for 1986.

Oryx Vol 21 No 1, January 1987 
Chad. The elephant population dramatically collapsed within a few months of the outbreak of civil war in 1979 (Reoyo, 1979; Lefol, questionnaire replies). Although this had numbered at least 15,000 , and possibly many more, recent estimates suggest that 2000-3000 remain in a vast range (Martin, 1985). The elephants are said to spend much of their time on the move. In 1985 there was still considerable commerce in ivory, some of it probably from neighbouring CAR where Chadian horsemen hunted with little impediment. The latest count of 1986 confirms the trend reported (Bousquet, pers. comm.).

Congo. The range is reported to have diminished by half in the 30 years prior to 1980 , and the military has been implicated in poaching (Nsosso, questionnaire replies).

Zaire. Elephants declined by approximately 60 per cent between 1976 and 1983 in the Garamba National Park, where they had formerly been among the very densest populations in Africa (Savidge et al., 1976; Hillman and Borner, 1983). It is likely that the decline in surrounding unprotected areas has been more severe. Large areas of north-east Zaire bordering on Sudan are reported as being devoid of elephants; they have been killed by Arab poachers armed with automatic weapons (Parry, 1983). In another part of Zaire along the CAR border, an elephant population was reported as relatively undisturbed as recently as 1984 (Hurt, questionnaire reply), but further east I saw no elephants on a one-hour flight in 1985 along the Mbomou river separating the two countries, where ten years earlier on an identical flight I had seen elephants in greater abundance than anywhere in my previous experience. The remaining elephants of northern Zaire, formerly the most densely populated elephant range in all Africa, are under constant threat from Arab poachers attempting to enter from CAR and Sudan (Parry, questionnaire reply). The ivory trade within the country has been an uncontrolled free-for-all for many years (Douglas-Hamilton, 1980). Zaire still has more elephant range than any other country, but all informants report massive declines, and I believe that the recent model of Martin (1985) estimating that 500,000 elephants remain in the country, is highly optimistic.
Gabon had an undisturbed population of elephants as recently as 1979 (DouglasHamilton, 1979a). The current status has not been reported although $\mathrm{Dr} R$. Barnes is currently carrying out an elephant research project in the field and reports considerable ivory poaching.

\section{East Africa (elephant range 1,866,000 sq km; 26 per cent of total range)}

East Africa's elephants are much better known, through census work, than those of West and Central Africa. The initial problems associated with elephant increase in the parks were first defined in this region, and each country has subsequently experienced massive declines of elephants within the majority of 'protected areas' where they are found.

Sudan. Arabs from the north, in bands of approximately 60 and armed with Kalashnikov and 63 automatic rifles, have raided protected and wilderness areas in the dry season. They often operate on horseback and camel (Parry, 1983; questionnaire replies), nullifying the elephant's prime defence of being able to outwalk its human predators. The army and police have also been implicated in elephant poaching and ivory trading (Boitani, 1981; Watson et al., 1976). There have been a few fragmentary aerial surveys, which support the widespread reports that elephant populations have collapsed (Boitani, 1981; Hillman et al., 1981). Carcass ratios in the Shambe National Park in 1981 suggest a decline of the order of 60 per cent in the previous five years (Hillman et al., 1981). In the best case it is likely that Sudan has lost half of its elephants since 1975; in the worst case the elephant decline may have equalled that of neighbouring Uganda, a population crash of 90 per cent in the space of five years.

Ethiopia. There has never been a properly organized elephant census but, according to Martin (1985), illegal hunting exceeds the sustained yield of the population, and the main source of legal ivory in the country is through confiscation. 
Somalia. Elephant poaching in Somalia was almost eliminated between 1971 and 1976. The elephants appeared to be expanding northwards, due to effective protection, but some elephants may also have immigrated to escape from poaching in Kenya at that time. An aerial survey in 1976 found the highest density of elephant carcasses along the Kenya border (Bunderson, Abel, questionnaire replies). Then, in 1977, poaching for ivory got under way at a much higher rate and the country was believed to have lost over half its elephants by 1981 (Omar, 1981). According to R. M. Watson (pers.comm.) the elephants have now largely been eliminated.

Kenya. Elephants came under heavy pressure from the ivory trade in the early 1970 s, and most populations outside protected areas were severely reduced by the mid-1970s. Carcass ratios from surveys conducted across the rangelands by the Kenya rangeland monitoring unit (Stelfox et al., 1981) suggest declines of the order of 80 per cent prior to 1981 . Kenya's most important elephant population, in the Tsavo National Park, probably numbered well over 40,000 in the late 1960s (Cobb, 1976; Otticholo, 1986). The trend of the Tsavo elephants shows an increase in the 1960s followed by a crash in two phases, firstly in 1971 due to drought and starvation, and secondly in 1975 and 1976 due to poaching for ivory (Otticholo, 1986). The population has shown a further decline since then. The second most important Kenyan population was found in the Lamu area, mainly outside reserves. It declined from 1976, with poaching reported as being exceptionally severe in 1980-1983. By 1985 , elephants had not been seen in the vicinity of the Kiwaiyu Tourist Camp for three years where formerly they had been plentiful (questionnaire replies). Apart from the Lamu area, elephant poaching in Kenya has not been reported as being as serious in the 1980 s as it was in the late 1970 s before the ban on private ivory trading.

Tanzania. Elephant poaching became established later in Tanzania than in Kenya, and began in the north of the country. A high proportion of dead elephants was seen on surveys in the Tabora and Arusha regions in 1979 and 1980, suggesting overall declines that varied between 16
25 per cent and 100 per cent through most of northern Tanzania (Ecosystems, 1979-1980). These trends spread to the south. The Selous elephant population, the largest known in Africa, which numbered over 100,000 in 1976 , is now declining after an initial period of natural increase and compression in the 1960 s. Surveys suggest a 20-30 per cent decline in elephants in the northern Selous between 1976 and 1981 (Douglas-Hamilton, 1984b), which has apparently become even more serious recently (Borner and Severre, 1985; questionnaire replies). Similar trends appear to be true of the Ruaha and Serengeti populations, both of which peaked in the 1970s and later showed major declines (Barnes and Douglas-Hamilton, 1982; Borner and Severre, 1984; Dublin and DouglasHamilton, 1986). Officials in the wildlife department see a total ban on all private ivory trading in worked and unworked ivory as the only solution for conserving Tanzania's elephants. Trends in Lake Manyara National Park do not follow the national pattern. Elephants increased in the 1950 s through immigration and in the late 1960 s through natural reproduction. In the absence of poaching or culling they have remained relatively stable, being controlled by periodic disease. The park is small and relatively well patrolled (Douglas-Hamilton, 1972; Weyerhaeuser, 1982).

Uganda. Elephant numbers in Queen Elizabeth and Murchison Falls National Parks showed increases in the 1960 s followed by catastrophes in the late 1970s, with declines of the order of 80-90 per cent (Douglas-Hamilton, 1980; Douglas-Hamilton et al., 1980; Eltringham and Malpas, 1980). Kidepo National Park had a migratory population, but from a count made in 1981 , the carcass ratio suggested a decline of 65 per cent in the previous four years (DouglasHamilton, 1983a). The cause in each case has been ivory poaching helped by easy availability of weapons and general chaos. Poaching was checked in 1980 by the National Park's rehabilitation programme (Kayanja and DouglasHamilton, 1982). Elephants remained stable at low densities, with some additions by immigration (Douglas-Hamilton, 1983a). No new reliable surveys have been made since 1982, and the Oryx Vol 21 No 1, January 1987 


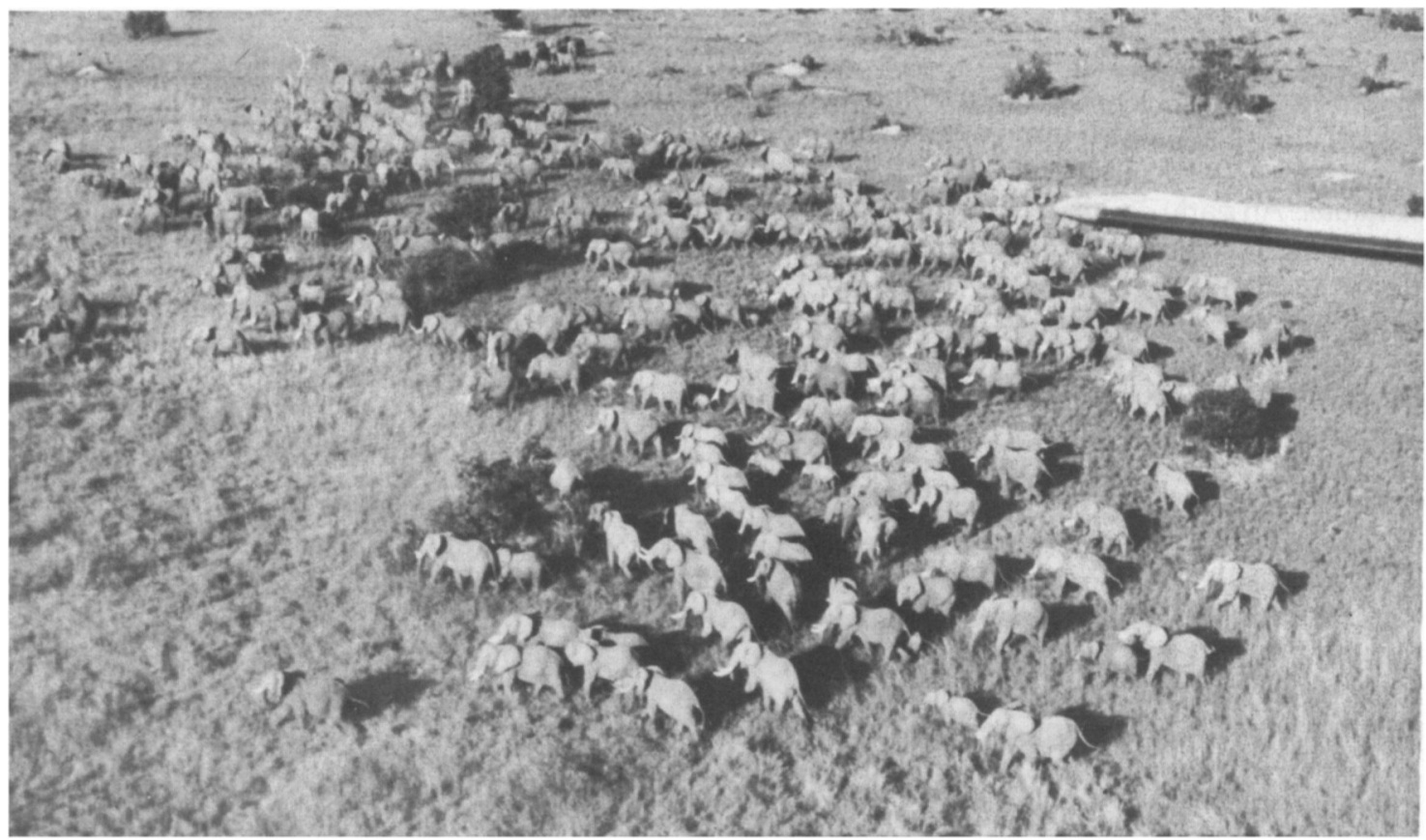

Doomed herd of elephants south of the Nile, Murchison Falls National Park, counted by the author in 1976. Virtually all these were killed by 1980 (I. and O. Douglas-Hamilton).

effects of the recent civil war have not yet been assessed.

Rwanda. In the Akagera National Park there are 25 elephants, survivors of an extermination when 106 adults were killed in 1975, and calves were immobilized and transported to the park (Haigh et al., 1979).

\section{Southern Africa (elephant range} $1,476,000 \mathrm{sq} \mathrm{km} ; 21$ per cent of total range

In Southern Africa elephants are decreasing in Angola, Mozambique and Zambia, but on the whole are stable or increasing in Botswana, Namibia, South Africa, Zimbabwe and Malawi.

Angola. No hard data are available on account of the war; rumours continue of guerillas trading ivory for arms, but no quantitative information is available.

Zambia. Early estimates of the most important Luangwa Valley elephant population suggest that African elephants: population trends elephants increased until the early 1970s, probably through compression and natural increase. In the 1979 aerial census it appeared that elephant numbers within the national park had declined from 56,000 to 33,500 since 1973 (Caughley and Goddard, 1975; DouglasHamilton et al., 1979). Counts in 1985 confirmed a further decrease of approximately 30 per cent, with more compression of the elephants into relatively safe areas (Kaweche and Lewis, pers. comm.).

Botswana. Botswana is one of the few countries where elephants are reported to be increasing. Although elephant poaching was a problem in the early 1980s, recent aerial surveys have returned record dry-season concentrations of elephants in the Chobe National Park and have shown that elephants are widely distributed at densities that compare favourably with the best ranges left on the continent (Melton, 1985; Patterson, 1985; Work, 1983).

Namibia. The population of the Etosha National Park is believed to be secure, but the elephants living in desert conditions in Kaokoland 
are threatened, numbers reported as falling from 3000 in 1962 to 220 in 1982 . Aerial censuses in 1982 uncovered clear evidence of poaching (Craven, 1984; Owen-Smith, 1984).

Malawi. An early count of the main population in Kasungu National Park gave an overestimate, due to faulty survey technique, of about 2500 , giving a total national value of $4000-4500$. Subsequent surveys have shown the Kasungu population to be around $800-1000$, giving a total for Malawi of about 2300. Elephant poaching in the park increased steadily from 1977 to 1981 and appeared to be compressing elephants into safe areas in the east and centre of Kasungu National Park. An anti-poaching campaign mounted in 1982 was apparently successful and relieved the compression, as elephants once more were safe to move further afield. It is reported that the elephant population is now more or less stable, and poaching of elephants is under control (Bell, 1984; questionnaire replies).

Mozambique. All information on this country is reported by Tello (questionnaire replies). The elephant range still covers one-third of the country, but the largest components in the centre and south of the country may have become fragmented since 1975. Until recently elephants in Niassa and Rovuma in the north and Marromeu in the centre of the country were reported as increasing and expanding their ranges, with only light poaching from across the border with Tanzania. Since 1982 the situation has deteriorated dramatically in the central and southern ranges. Increasing civil strife has led to units of the army, the militia and the 'resistance' each poaching in areas that they control. Gorongoza National Park has been overrun by rebels, who have killed elephants for ivory and meat, reducing their numbers from an estimated 6000 to 2000 . In the centre and west of the country, the fall in elephant numbers is estimated to be of the order of 65 per cent in the space of two years. Only in the Zambezi Utilization Area was there some increase, due to immigration. Pitched battles have been fought between rebels and wildlife department staff in this area. In the south, declines are believed to be more severe, of the order of 76 per cent, with the exception of Maputo Reserve where numbers are still esti18 mated around 200. Tello's national elephant estimate fell from approximately 50,000 in 1982 to fewer than 30,000 in 1984.

Zimbabwe. There were believed to be approximately 40,000 elephants in Zimbabwe in 1981. The war had not affected their status adversely; if anything, it had permitted an increase in range in some parts of the country. With the cessation of the war, there was an upsurge of elephant poaching on the Botswana border, but this was quickly brought under control. The elephant population of Zimbabwe has been showing an increase of about 5 per cent per anum. Hwange National Park reflects this trend (Cumming, questionnaire replies). There are now probably ten times as many elephants in the country as there were at the turn of the century. Increasing elephant populations, coupled with decreasing range, have resulted in large-scale changes to woodland in parts of some of the protected areas. A policy of maintaining woodland communities has led to culling for conservation reasons, and local people have benefitted from these culling operations (Cumming, pers.comm.). The status of elephants is similar to what it was in East Africa in the 1960s, with apparently secure elephants living at high densities in the parks, and numerous external populations that can be hunted for sport. The Department of Wildlife and Parks has shown what can be achieved with adequate protection and control of the ivory trade. Equally, if deprived of that protection and control the elephants could decrease in the future.

South Africa. Elephants in the Kruger National Park are now held stable by culling, after a dramatic increase through immigration and natural reproduction up to the 1970s (HallMartin, 1981; Van Wyk and Fairall, 1969). Poachers from Mozambique armed with automatic rifles killed over 100 elephants in the early 1980 s, but they have been contained (HallMartin, questionnaire replies). In the south, over 100 elephants in the Addo National Park have the highest recorded rate of increase on the continent, 7 per cent per year (Hall-Martin, 1980). This is an example of how elephant populations can recover from the brink of extinction if the area they live in becomes adequately protected.

Oryx Vol 21 No 1, January 1987 


\section{Factors affecting elephant trends}

During the 1960s, elephants compressed into many African national parks caused extensive woodland destruction. Classic examples were the Murchison Falls National Park in Uganda and the Tsavo National Park in Kenya. The price of ivory in real terms remained stable over the decade as a whole. Poaching was brought well under control in most parks.

In the 1970s the situation changed dramatically. The value of ivory in real terms increased significantly. Simultaneously, reports of elephant population decline became common, and many African countries entered into an explosive arms race, accompanied by civil disturbances, wars and guerilla campaigns. The impact of these latter factors, and the increased availability of automatic weapons on elephant population dynamics, need to be taken into account (Douglas-Hamilton, 1983b; Burrill et al., 1986).

\section{Ivory prices}

From 1960 to 1969 the international trade price of raw ivory moved little, averaging $\$ 5.45$ per $\mathrm{kg}$, plus or minus 20 per cent. In 1970, however, it jumped to $\$ 7.44$ and went on climbing to a peak of $\$ 74.42$ in 1978 (Parker, 1979). The price dropped to $\$ 52.80$ per $\mathrm{kg}$ in 1982 , but has since risen to over $\$ 100$ per $\mathrm{kg}$. These rises were greatly in excess of inflation, and when the effects of inflation are removed, the real value of ivory was six times higher in 1978 than in 1960. Changes in the real value of ivory are presented in Figure 1 as an index, with a base of 100 in 1960 . At no time since 1973 has the real value been less than three times its average for the 1960s.

The reasons for this price rise are not fully understood, although it has been suggested that investors were attracted to ivory as a wealth store in a time of high inflation. The result has been to increase incentives to obtain and trade in ivory. The price increases have worked their way down the economic chain to the primary producer, the poacher who kills elephants. The price obtained by a poacher, although only a fraction of the international price, has experienced equivalent or greater increases (Douglas-Hamilton, 1979b).

African elephants: population trends
There are therefore good grounds for supposing that the entire ecology and future prospects of the African elephant have been negatively affected by the leap in the ivory price rise and consequent excessive human predation.

\section{The arms race}

In recent years, the use of automatic rifles in elephant poaching has been reported in a large number of national parks: Niokola-Koba in Senegal, Zakouma in Chad, Garamba in Zaire, Bamingui-Bangoran in CAR, the Luangwa Valley in Zambia, Hwange in Zimbabwe; Chobe in Botswana, Gorongoza in Mozambique, the Kruger in South Africa, and many in East Africa (Douglas-Hamilton, 1983a). These weapons clearly originated from outside the continent.

According to the US Arms Control and Disarmament Agency (1983), the value of arms imports to Africa increased (in real terms) from $\$ 500$ million in 1971 to $\$ 4500$ million in 1980 ; military expenditure in Africa during the same period increased at an annual average rate of 6.66 per cent. Eastern Africa provides a particularly potent case study. Somalia armed in the early 1970s in preparation for the Ogaden war, inducing similar action from Ethiopia. As Uganda expanded its military forces under Amin, Tanzania and then Kenya felt compelled to follow suit. Sudan expanded its military capability in order to resist Libyan interference.

Armed forces in the region increased from 141,000 in 1971 to 441,000 in 1980 (US Arms Control and Disarmament Agency, 1983). It seems reasonable to assume that the number of automatic rifles will be related to this dramatic increase in the number of men serving in the armed forces in the region. A critical question is how so many of these weapons came to be used for poaching. In some countries, for example Uganda and Sudan, elements of the military themselves were the main poachers, and the lightly armed and outnumbered park rangers were powerless to oppose them. In other cases weapons were lost, stolen, taken from defeated soldiers, looted from armouries, issued to people's militias, channelled secretly to guerilla movements, or simply traded by soldiers for money or goods. In much of Central Africa ivory 
'collectors' gave guns to villagers and paid them for ivory recovered (personal obs; questionnaire replies; Mulder and Caro, 1980).

The proliferation of weapons was increased by wars and civil strife. For example, as Amin's power weakened in Uganda, the Matheniko clan of the Karamajong tribe attacked and overwhelmed the police barracks at Moroto. In this raid they looted the armoury and carried off 12,500 automatic rifles, 1.5 million rounds of ammunition, and numerous rocket-propelled grenades and other munitions. The Jieh clan also participated in this haul (Avergan and Honey, 1982).

The Matheniko and the Jieh clans then attacked other clans and accumulated stolen cattle. The market for these cattle and the loose guns spread. When one tribe acquired new weapons, the others were under pressure to keep up or suffer defeat. Thus, a chain-reaction of weapon acquisition was set off. From the Karamajong in Uganda the Toposa acquired rifles and took them to Sudan, and the Turkana brought rifles to Kenya. The Pokot acquired them too as they were traded through the tribes (Avergan and Honey, 1982).

In 1979 retreating troops of Amin were eager to abandon their weapons and uniforms in order to avoid capture and execution. When they could, they sold their guns to villagers. Their retreat back to West Nile Province, from where most of them came, lay through the Murchison Falls National Park. Hundreds of rifles came into the hands of local people in that area, and they began to poach.

Further east the Somalis built up their army with the policy of extending their boundaries to include the Somali communities living in Ethiopia, French Somaliland and Northern Kenya. Somali 'shifta' were responsible from 1970 to 1975 for reducing elephant populations along the Tana River and in the Lamu Garissa region of Kenya.

In the 1977 Ogaden war, Somali insurgents developed a trail across Northern Kenya in the Mandera area. Inevitably some of these guerillas, who were probably not well disciplined, deserted or sold or lent their arms to others. The spin-off 20 was that more loose guns wound up in the hands of the nomads.

It was not until this point that elephant poaching in Somalia itself got under way. Formerly, it had been reported that poaching had been virtually eliminated in the country. Elephant poaching suddenly increased with the easy availability of automatic weapons associated with the war between the Western Somalia Liberation Front and Ethiopia. In the five years previous to 1981 over one-half of the elephants of the country were killed, and in many areas this proportion was surpassed. There were places where the antipoaching unit found groups of up to 80 dead elephants.

To the south, in Tanzania, loose guns have also increased. I found a group of eight dead elephants in the Tarangire National Park on an aerial survey in 1977, an apparently expert killing. In 1981 Tanzanian troops returned from Uganda, undisciplined, looting, and 'losing' guns.

At the end of the Sudanese civil war in 1974 many of the Southern 'Anyanya' guerillas were recruited into the army and issued with automatic weapons. As a result of the recent civil disturbances an anarchical situation exists in which elements of the army, government officials, ex 'Anyayas', and gangs of well-armed horsemounted Arabs have been involved in a free-forall, which appears to have decimated every elephant population in the southern Sudan.

\section{Human population growth}

Human population growth is an issue of critical importance in the developing countries, particularly in Africa. Competition for land use with expanding human populations has already resulted in the loss of valuable wildlife habitat in many countries. If population growth in Kenya continues at the current 4 per cent rate, the highest in the world, the population will double in less than 18 years. Continuation of current trends will inevitably challenge the integrity of protected areas and threaten the existence of large mammals.

Competition for land use arising from human population growth has been proposed as the 
major factor responsible for the recent decline in elephant numbers (Parker and Amin, 1983; Parker and Martin, 1982). During the last decade, however, the expansion of human populations in rural areas has not matched the overall growth rates in many parts of Africa due to movements into urban areas. Furthermore, decreases in elephant numbers have frequently been recorded in areas of low human population density where competition for land use is minimal. Examples include Sudan, Chad, CAR and Northern Zaire.

In comparison with the rapid and widespread escalation of poaching encouraged by the factors discussed earlier, the suggestion that human growth could be the main factor accounting for elephant decreases of the last decade is implausible.

\section{Comparison of factors}

The factors affecting elephants can be compared by considering their relative rates of change during the 1960s and 1970s. The average dollar value of ivory in the 1960 s increased in real value by three times for the period 1970-1982. Between 1971 and 1980 the real value of arms imported into the East African region increased by at least nine times and armed forces by three times, whereas the human population only increased by 50 per cent in the country of most rapid growth, Kenya.

The critical importance of establishing effective anti-poaching measures and rigorous control over the ivory trade as a top priority for conservationists seems clear; however, information obtained from the trade itself has in the past led to underestimates of the effect of the trade on elephant populations (Parker and Amin, 1983). Of what does this trade information consist?

\section{Information from the ivory trade}

An extensive study of the ivory trade, which I commissioned from Parker (1979) on behalf of the US Fish and Wildlife Service, and subsequent reports from Parker and Martin (1982, 1983), concluded that the ivory trade does not pose an immediate crisis for elephants, and that human population increase is the key to the decline in African elephants: population trends elephant numbers. More recently, Martin (1985), in a study for CITES, has concluded from computer modelling that the overall elephant population of Africa is declining at a rate of less than 2 per cent, despite the contradiction offered by the majority of field data quoted earlier.

Parker and Martin's argument is developed in the following stages: the total weight of ivory exported from the African continent is estimated from customs returns of certain importing countries, primarily Hong Kong and Japan; the number of tusks, and therefore elephants, is then calculated from an estimate of the average weight of each tusk; this figure is then compared to continental population estimates and judged too small to be significant.

Their analysis rests upon certain critical assumptions:

(i) that the amount of ivory traded outside Africa can be determined accurately from an analysis of trade statistics and customs returns prepared by the leading importing countries;

(ii) that this data can be combined with mean tusk weights obtained from Hong Kong import licences and CITES records to evaluate the overall effect of the ivory trade on elephant populations.

Is it realistic to suggest that official import statistics give an accurate picture of the world ivory trade, and that the amount of ivory, both worked and unworked, leaving Africa undocumented is very small? Two examples, which I have come across personally, suggest otherwise.

In Ivory Coast 29 tonnes of raw ivory were imported in 1977 (Douglas-Hamilton, 1979b), but only 0.6 tonnes of worked ivory and 0.5 tonnes of raw ivory were officially exported. The imported ivory went almost entirely to supply the ivory carving industry. One can reasonably assume that most of these 29 tonnes were sold to local expatriates or tourists, and eventually disappeared overseas classified as personal effects, without appearing in any export or overseas import statistics.

A second example of ivory leaving the continent undocumented took place in Burundi. I was reliably informed that an estimated 120 tonnes of ivory were fraudulently flown out on a well-known 
airline in 1981 and 1982 as unaccompanied luggage. The reason for this deception was to avoid paying freight charges on ivory of $\$ 5-6$ per $\mathrm{kg}$, rather than the lower charge of $\$ 2$ per $\mathrm{kg}$ on unaccompanied luggage. The amount is not trivial. It comes to nearly 10 per cent of Africa's ivory exports estimated by TRAFFIC for those years (WTMU, 1983). There is no reason to suppose that this smuggled ivory would necessarily appear in overseas import statistics. This amount was carried by only one airline from one country. If all such instances were known, the true exports could be greatly multiplied. Worked ivory leaving in the diplomatic bag is also probably very significant.

The inherent difficulty in estimating reliable parameters from international trade data was further illustrated by the omission of the export of 315 tonnes of ivory in 1977 from Sudan to Saudi Arabia (Parker, 1979). Subsequent recognition of this shipment showed that original estimates of total African ivory exports for that year had been understated by 27 per cent (Parker and Martin, 1983). It is conceivable that other similar shipments may have been overlooked temporarily, and others may have gone entirely undetected.

The next important question is how many elephants the ivory exports, primarily recorded by weight, actually represent. The reliability of the answer depends on the mean tusk weight used in the calculation. Hong Kong import licences examined by Parker in 1978 gave a figure of 9.65 $\mathrm{kg}$, which forms the basis of subsequent calculations. Yet estimates for Hong Kong mean tusk weights in later years collected by the Wildlife Trade Monitoring Unit of the IUCN are much lower at 5.39-5.75 kg (WTMU, 1983). WTMU also reported a decline in mean tusk weights of Japanese imports from $16.29 \mathrm{~kg}$ in 1979 to $9.7 \mathrm{~kg}$ in 1982 [Parker and Martin (1983) maintain that the size of Japanese tusks remained constant during this period]

If, as these data suggest, there has been a rapid overall drop in mean tusk weight, the implication is that smaller and younger elephants are being killed for ivory under conditions of severe overexploitation. This conclusion is supported by evidence of a drop in Hong Kong mean tusk weights (Caldwell and Barzdo, 1985), and in the 22 very low mean tusk weights of ivory confiscated from poachers in Uganda and CAR, which I have measured at 2.7 and $3 \mathrm{~kg}$, respectively. Alternatively, if the $9.65 \mathrm{~kg}$ mean value was in fact an overestimate, then the number of elephants calculated by Parker and Martin from trade figures was an underestimate.

They also appear to have overestimated the amount of ivory collected from elephants succumbing to natural mortality, and claimed that this source accounts for 20 per cent of African ivory exports. However, field data collected by Cumming suggest that only 1 per cent of Zimbabwe's ivory comes from this source. In any case, much of the so-called 'found ivory' described by Parker is likely to have come from elephants that have died from wounds caused by man, as was pointed out by Sheldrick at Tsavo (Sheldrick, 1976). According to Bell (pers. comm.), 85 per cent of the elephants found dead by rangers in Malawi have died of wounds.

In summary, the earlier arguments (Parker, 1979; Parker and Amin, 1983; Parker and Martin, 1982, 1983), which suggested that concern expressed over killing elephants for ivory was exaggerated, are largely based upon an illusion of accuracy of ivory trade records, an ignorance of elephant trends then current, and optimistic assumptions about elephant numbers. They rely on ivory trade data that, at best, provide very minimal estimates of elephant mortality due to ivory poaching. The difficulties of interpreting such data have been recognized by Caldwell and Barzdo (1985).

\section{Conclusion}

Elephants represent a valuable aesthetic and economic asset now rapidly depleted by killing for ivory, rather than by human population growth. Any discussion of the rational management of elephants as a renewable natural resource, whether for ivory, meat or tourism, is academic if managers cannot prevent their destruction. The premature elimination of elephants over much of their range represents one of the most wasteful mammalian tragedies of this century. Conservation measures must be implemented at two levels: the trade in ivory products must be rigorously controlled, or eliminated, and the illegal Oryx Vol 21 No 1, January 1987 
killing of elephants in protected areas must be significantly reduced.

A total ban in private ivory trading was implemented in Kenya in 1978, and a similar moratorium may well be the best solution in other countries until such time as elephant herds can build up. A moratorium would not only protect the elephants, but could eventually lead to greater production of ivory through the harvesting of that produced by natural mortality. This is because older elephants produce more ivory per year than young ones, and leaving a population to grow old would maximize ivory production (Pilgram and Western, 1984).

The banning of raw ivory exports from Sudan in 1983 and Belgium's ratification of CITES are steps in the right direction, but are unlikely to be effective on their own. Zaire banned all ivory exports in 1980 but, despite notifying the CITES secretariat to that effect, has not been adequately helped by importing nations. Even the US imported Zaire ivory in 1985 , despite their compliance with CITES (Caldwell and Barzdo, 1985; Martin, 1985). Most of Zaire's ivory leaves under false labels of origin, through ports of convenience in neighbouring countries.

It is clear that efforts to date have fallen far short of the stringent measures required to halt the illegal and underground traffic that continues. The recent measures proposed by African members of CITES to define quotas of ivory within the bounds of sustained yield (Martin, 1985) now offer the chance of effective action, but only to the extent that they can be enforced. Unfortunately, it is enforcement capability that is lacking. Furthermore, under the new system, ivory confiscated by the authorities may be added on top of the declared exports, which may prove to be a loophole. Nor will the new measures touch the invisible trade that is smuggled or leaves in the diplomatic bag.

United international police action to combat the illegal ivory trade is still urgently needed, especially the use of ivory databases to prevent traders 'whitewashing' ivory of illegal origin, which at present forms most of the trade. The newly formed Ivory Trade Monitoring Unit of CITES can serve elephant conservation if it leads to such action.

African elephants: population trends
In the 'protected areas' emphasis needs to be on supporting the man in the field, who should be trained and equipped to resist extensive, wellarmed poaching operations. Without this the future looks bleak for elephants. Emphasis on disciplined field forces will be unpalatable to many conservationists. Unfortunately, enforcement of the law within the remaining protected areas' is essential if they are to justify that name.

\section{References}

Avergan, T. and Honey, M. 1982. War in Uganda. Tanzania Publishing House Ltd, Dar-es-Salaam.

Barnes, R.F.W. and Douglas-Hamilton, I. 1982. The numbers and distribution patterns of large mammals in the RuahaRungwa area of southem Tanzania. J. Appl. Ecol. 19, 411-425

Bell, R.H.V. 1984. Letter to the Editor. Swara, 7, 40.

Boitani, L. 1981. The Southern National Park, a Master Plan. Prepared for Instituto di Zoologia, Facolta di Scienze dell'Universita di Roma, Italy.

Borner, M. and Severre, E. 1984. The Ruaha Elephants. Report from the Ministry of Lands, Natural Resources and Tourism, Tanzania.

Borner, M. and Severre, E. 1985. Rhino and Elephant Poaching in the Selous Game Reserve. Serengeti Wildlife Research and Frankfurt Zoological Society.

Bousquet, B. and Szaniawski, A. 1981. Benin et Haute Volta. Resultats des Recensements Aeriens de Grands Mammiferes dans la region Pendjarie et Mekrou. FO:DP/ UPV/78/008 DP/BEN/77/011. Document de Terrain No. 4.

Bryden, H.A. 1903. The decline and fall of the South African elephant. Fortnightly Review (n.s.), 79, 100-108.

Burrill, A., Douglas-Hamilton, I. and Mackinnon, J. 1986. Protected Areas as Refuges for Elephants. IUCN, Gland, Switzerland

Caldwell, J.R. and Barzdo, J. 1985. The World Trade in Raw Ivory, 1983 and 1984. Wildlife Trade Monitoring Unit report to CITES.

Carrington, R. 1958. Elephants, a Short Account of their Natural History, Evolution and Influence on Mankind. Penguin, London.

Caughley, G. and Goddard, J. 1975. Abundance and distribution of elephants in the Luangwa Valley, Zambia. East African Wildlife J. 13, 39-48

Cobb, S.M. 1976. The distribution and abundance of the large herbivore community of Tsavo National Park, Kenya. D.Phil. Thesis. University of Oxford.

Craven, D. 1984. Damaraland and Kaokoland-Where to Now? Namibia Wildlife Trust Newsletter. Winter 1984.

De Bie, $\mathrm{S}$ and Kessler, J.J. 1983. An Aerial Resource Inventory of the National Park Boucle du Baoule. Department of Nature Conservation, Agricultural University, Wageningen, The Netherlands.

Douglas-Hamilton, I. 1972. On the Ecology and Behaviour of the African Elephant. D.Phil Thesis. University of Oxford.

Douglas-Hamilton, I. 1979a. The African Elephant Action Plan. Typescript report for the IUCN/WWF/NYZS Elephant Survey and Conservation Programme. 
Douglas-Hamilton, I. 1979b. African Elephant Ivory Trade. Final Report to US Fish and Wildlife Service.

Douglas-Hamilton, I. 1983a. Back from the brink. AERSG Newsletter, 1, 13.

Douglas-Hamilton, I. 1983b. Elephants hit by African arms race. Pachyderm, 2, November 1983.

Douglas-Hamilton, I. 1984a. Trends in key African elephant populations. Pachyderm, 4, 7-9.

Douglas-Hamilton, 1. 1984b. Elephant and rhino populations trends in Selous, Tanzania, Pachyderm, 4, 18.

Douglas-Hamilton, O. 1980. Africa's elephants-can they survive? National Geographic Magazine, 158, 568-603.

Douglas-Hamilton, I., Froment, J.M., Doungoube, G. and Root, J. 1985. Amenagement Faune Republique Centrafricaine. Recensement aereien de la faune dans la zone nord de la Republique Centrafricaine, FO: CAF/78/006 Document de travail 5.

Douglas-Hamilton, I., Hillman, A.K.K., Holt, P. and Ansell, P. 1979. Luangwa Valley. IUCN/NYZS WWF Elephant, Rhino and Wildlife Survey.

Douglas-Hamilton, I., Malpas, R., Edroma, E., Holt, P., Laker-Ajok, G. and Weyerhaeuser, R. 1980. Rwenzori National Park and Kabalega National Park Aerial Counts. IUCN Progress Report. Uganda Elephant Survey. Uganda Institute of Ecology.

Dublin, H. and Douglas-Hamilton, I. 1986. Current Status and Past Trends of Elephants in the Serengeti and Mara ecosystems (in press).

Ecosystems 1979-1980. Aerial Survey Reports in Tanzania Ecosytems Ltd, Nairobi.

Eltringham, S.K. and Malpas, R.C. 1980. The decline in elephant numbers in Rwenzori and Kabalega Falls National Parks, Uganda. Afr. J. Ecol. 18, 73-86.

Froment, J.M. 1985. Exploitation des Elephants en Republique Centrafricaine. Document de terrain No. 1 , $\mathrm{CAF} / 78 / 006, \mathrm{FAO}$.

Haigh, J.C., Parker, I.S.C., Parkinson, D.A. and Archer. A.L. 1979. An Elephant Extermination. Environmental Conservation, 6, 305--310.

Hall-Martin, A. 1980. Elephant survivors. Oryx, XV, 355362.

Hall-Martin, A. 1981. Conservation and management of elephants in the Kruger National Park, South Africa. IUCN/SSC AERSG proceedings at Hwange Safari Lodge, Zimbabwe.

Hillman, A.K.K. and Borner, M. 1983. Aerial Census of the Garamba National Park, Zaire. Report of WWF/FZS. Typescript

Hillman, A.K.K., Snyder P.M., Tear, T. and Sommerlatte, M. 1981. An Aerial Reconnaissance of the Shamba Area, Southem Sudan. Typescript report.

Kayanja, F. and Douglas-Hamilton, I. 1982. Impact of the Unexpected-Case History of the Uganda National Parks. Bali Conference.

Martin, R. 1985. Establishment of African Ivory Export Quotas and Associated Control Procedures. A report to the CITES secretariat.

Melton, D.A. 1985. The Status of elephants in Northern Botswana. Biological Conservation, 31, 317-333.

Mulder, M.B. and Caro, T. 1980. Slaughter of the Elephants. New Scientist, July, 32-34.

Olivier, R.C.D. 1983. The Gouma Elephants of Mali. A 24
Challenge for the Integrated Management of Sahelian Rangeland. UNEP, Nairobi. Typescript.

Omar, H.S. 1981. Save the elephants from extinction in Somali. Somali Range Bulletin, 12, 67-70.

Otticholo, W.K. 1986. Population estimates and distribution patterns of elephants in the Tsavo ecosystem, Kenya, in 1980. African Journal of Ecology, 24, 53-57.

Owen-Smtih, G. 1984. Namibia's most valuable resource. Quagga, 7. Spring 1984.

Parker, I.S.C. 1979. The Ivory Trade. Report to I. DouglasHamilton on behalf of the US Fish and Wildlife Service.

Parker, I.S.C. and Amin, M. 1983. Ivory Crisis. Chatto and Windus, London.

Parker, I.S.C. and Martin, E.B. 1982. How many elephants are killed for the ivory trade? Oryx, XVI, 235-239.

Parker, I.S.C. and Martin, E.B. 1983. Further insight into the international ivory trade. Oryx, XVII, 194-200.

Parry, D. 1983. Slaughterhouse of the Giants. Quagga, 7, $32-33$.

Patterson, L. 1985. Aerial Monitoring of Major Wildlife Species in Northern Botswana. Third Survey, Kalahari Conservation Society.

Pilgram, T. and Western, D. 1984. Managing elephant populations for ivory production. Pachyderm, 4, 9-11.

Reoyo, M.T. 1979. Le Parc National de Zakouma En Peril: Destruction Systematique des animaux par de Militaires. Typescript report.

Roth, H.H., Merz G. and Steinhauer, B. 1984. Repartition et Statue des grandes mammiferes en Cote d'lvoire. Mammalia, 48, 207-226.

Savidge, J.M., Woodford, M.H. and Croze, H. 1976. Report on a Mission to Zaire. FAO (KEN/71/526-ZAl/70/001).

Sheldrick, D.L.W. 1976. Report on Poaching in the Tsavo National Park. Typescript report.

Stelfox, J.G., Kafwafwa, J.W., Otticholo, W.K. 1981. Distributions and population trends of elephants and rhinoceros in Kenya: 1977-1981. KREMU Technical Report No. 43. Ministry of Tourism and Wildlife, Nairobi.

Teleki, G. 1980. Status of the Elephant (Loxodonta africana) in Sierra Leone. A Preliminary Report on Distributions. Report to WWF. Typescript.

US Arms Control and Disarmament Agency. 1983 World Military Expenditures and Arms Transfers. US State Dept.

Van Wyk, P. and Fairall, N. 1969. The influence of the African elephant on the vegetation of the Kruger National Park with special reference to the tree and shrub strata. Koedoe, 12, 57-89.

Verschuren, J. 1981. Senegal's disappearing elephants. Oryx XVI, 118-119.

Verschuren, J. 1982. Hope for Liberia. Onyx, XVI, 421-427.

Watson, R.M., Thackway, R.M., Tippet, C.I. and Scholes, V.A.D. 1976. Sudan National Livestock Census and Resource Inventory. Typescript. 20 volumes

Wells, M. and Douglas-Hamilton, I. 1986. Tusk size CAR. Pachyderm 6, 16.

Weyerhaeuser, R. 1982. On the ecology of the Lake Manyara elephants. Masters Thesis. Yale University.

Work, D.R. 1983. Chobe Elephant Survey Interim Report. Typescript report

WTMU. 1983. The Hong Kong and Japanese Trade in Unworked Ivory 1979-1982. Traffic Bulletin, 5, 7-10.

lain Douglas-Hamilton, PO Box 54667, Nairobi, Kenya.

Oryx Vol 21 No 1, January 1987 